\title{
The alien boatman Trichocorixa verticalis verticalis (Hemiptera: Corixi- dae) is expanding in Morocco
}

\author{
Taybi Abdelkhaleq Fouzi ${ }^{1}$, Mabrouki Youness ${ }^{1}$, Chavanon Guy ${ }^{1}$, Berrahou Ali ${ }^{1}$ and Millán \\ Andrés ${ }^{2}$
}

${ }^{1}$ Université Mohamed Premier, Faculté des Sciences, Département de Biologie, Laboratoire Sciences de l'Eau, l'environnement et du Développement Durable, B.P. 524, Oujda, Morocco.

2 Departamento de Ecología e Hidrología, Facultad de Biología, Universidad de Murcia, 30100 Espinardo, Murcia, Spain.

* Corresponding author: acmillan@um.es

Received: 03/12/18 Accepted: 09/04/19

\begin{abstract}
The alien boatman Trichocorixa verticalis verticalis (Hemiptera: Corixidae) is expanding in Morocco

This paper updates the presence of the Nearctic "water boatman" Trichocorixa verticalis verticalis in North Africa, showing a new range of the alien species that strongly have increased its distribution area in Morocco since its first record in 2010. Statistical analyses confirm a significant correlation between salinity and abundance of $T$. v. verticalis, highlighting the halobiont behavior of this invasive species, being this trait one of the main causes of its expansion success in the Atlantic and Mediterranean coast of the study area.
\end{abstract}

Key words: Trichocorixa verticalis verticalis, aquatic bug, exotic species, invasion, Ramsar wetlands, salinity, Morocco

\section{RESUMEN}

\section{El chinche acuático invasor Trichocorixa verticalis verticalis (Hemiptera: Corixidae) se está expandiendo en Marruecos}

Este trabajo actualiza la presencia del "chinche acuático" Nearctico Trichocorixa verticalis verticalis en el norte de África, mostrando un nuevo rango de la especie exótica que ha aumentado considerablemente su área de distribución en Marruecos desde su primer registro en 2010. Los análisis estadísticos confirman una correlación significativa entre la salinidad y la abundancia de T. v. verticalis, destacando el comportamiento halobionte de esta especie invasora, siendo este rasgo una de las principales causas de su éxito de expansión en la costa atlántica y mediterránea del área de estudio.

Palabras clave: Trichocorixa verticalis verticalis, insecto acuático, especie exótica, invasión, humedales Ramsar, salinidad, Marruecos 


\section{INTRODUCTION}

Humans have assisted the movement of other species beyond their natural ranges for centuries (Wilson et al., 2009). However, their role in shaping biota increased exponentially over time, especially throughout the $20^{\text {th }}$ century (Hulme et al., 2009). Biological invasions are one of the top threats to biodiversity and ecosystem functioning worldwide, and freshwater systems are among the most invaded ecosystems in the world (Fenoglio et al., 2016), having proportionally more invaders than terrestrial systems (Vitousek et al., 1997). In fact, globally freshwaters have been subjected to periodic deliberate and accidental introductions of alien species. Typical sources of invader introductions are ballast waters, pet, aquarium and ornamental trade, sport fishing and aquaculture (Nunes et al., 2015). In addition, exploitation and pollution of these waters and conversion to agriculture or urbanization also increase the likelihood of the alien species establishment and spread worldwide throughout degraded habitats (Dudgeon et al., 2006).

Nonetheless, for the majority of these invaders, the effects on the occupied systems are largely unknown. Although not all alien species have appreciable effects on the invaded ecosystems, many of them have been often implicated in species extinction, habitat degradation and ecosystem alteration (Clavero \& García-Berthou, 2005). Invasive species can bring serious threats to the conservation of protected areas (Lonsdale, 1999; Lovejoy, 2006). The "cordgrass" Spartina densiflora Brongn, the "water hyacinth" Eichhornia crassipes (Mart.), the "crayfish" Procambarus clarkii (Girard), the "zebra mussel" Dreissena polymorpha (Pallas), and the "mosquitofish" Gambusia holbrooki Girard are good examples of invaders that have detrimental effects on protected ecosystems (Caiola \& Sostoa 2005; Pimentel et al., 2005; Castillo et al., 2008; Cruz et al., 2008; Laranjeira \& Nadais, 2008; Savini et al., 2010). Whilst some taxonomic groups are well represented in alien invertebrate species lists, insects are highly under-represented (Balian et al., 2008), particularly aquatic ones, which do not seem to show this kind of behavior (Fenoglio et al., 2016).
A recent addition to these lists is the North American "water boatman" Trichocorixa verticalis verticalis (Fieber, 1851) (hereafter Tvv). This subspecies represents one of the few alien aquatic insects found in the world (Carbonell et al., 2017). Tvv inhabits brackish and saline water bodies, even occurring in the open sea (Hutchinson, 1931). Originally, it was widely distributed through the Atlantic coast of North America and the Caribbean islands (Carbonell et al., 2012). However, this corixid has also been recorded quite far from its area of distribution, such as New Caledonia (Jansson, 1982), KwaZulu-Natal in southern Africa (Jansson \& Reavell 1999), and recently, Spain, Portugal and Morocco (Guareschi et al., 2013).

In Spain, it was detected in the southwest (Günther, 2004), including wetlands from Doñana (Millán et al., 2005; Rodríguez-Pérez et al., 2009). In Portugal, it was primarily recorded from the South (Sala \& Boix 2005; Kment, 2006). Since its first detection in the Iberian Peninsula, $T v v$ has moderately increased its distribution area (Carbonell et al., 2012), being dominant in permanent saline waters, but rare in freshwaters, where native corixids are dominant (Coccia et al., 2013). In Morocco, it was discovered for the first time in irrigation channels in the Tahaddart river basin, posteriorly in the lowland of the Loukkos river and finally in the swamps of Smir lagoon (L'Modhi et al., 2010), apparently showing a halobiont behavior (see Hutchinson, 1993).

In this study, we aim to upgrade the available data of $T v v$ in Morocco and to determine the main environmental factors favoring its distribution and expansion in this country, trying to confirm its halobiont behavior.

\section{MATERIAL AND METHODS}

\section{Surveys}

Several campaigns were carried out between 2014 and 2017, on both Mediterranean and Atlantic coasts of Morocco seeking the alien species. Sampling sites were selected to cover all of the different environmental conditions and water-body types (mouth rivers and streams, irrigation channels, lagoons, ponds, salt marshes and salt-pans) 
in the coast or near it, where the alien species finds the most favorable habitats (Guareschi et al., 2013). All the sampling campaigns were carried out following the same protocol (see below) and supervised by the senior author of this study (AM), including those achieved in L'Mohdi et al. (2010) and L'Modhi (2016).

At each sampling site, all macroinvertebrates were collected from a representation of mesohabitats, always applying a multihabitat protocol (Jáimez-Cuéllar et al., 2002). The procedure consisted of dragging a kick-net of $0.10 \mathrm{~mm}$ mesh pore (diameter of the opening $25 \mathrm{~cm}$ and depth 45 $\mathrm{cm}$ ) and "D" shape. Each kick-sample was examined in the field until no new taxa were found with cumulative net strokes. For each sample, all the individuals belonging to the Corixidae family found were extracted and preserved in separate vials and fixed with alcohol $96 \%$. The remaining material was also preserved in vials with alcohol 70 or $96 \%$. In the lab, corixids were carefully examined looking for individuals of $T v v$, which were subsequently counted, thus obtaining a comparable relative estimate of the abundance of this species for each sampling site.

Harvested corixids were identified in the laboratory using specialized literature (Jansson, 1986; Gheit, 1994; Nieser et al., 1994; Günther, 2004; L'Modhi et al., 2010). The recorded species were preserved in duly labeled tubes and deposited in the collection of aquatic macroinvertebrates at the Laboratory of Water Sciences, Environment and Sustainable Development of the University Mohammed Premier from Oujda (Morocco), and the Department of Ecology and Hydrology, Faculty of Biology, University of Murcia (Spain).

Parallel to the sampling fauna, each sampling site was subjected to in situ measures of five physicochemical parameters (mean water depth, temperature, $\mathrm{pH}$, electrical conductivity and salinity), all considered of special concern in the distribution of aquatic macroinvertebrates, particularly corixids (Carbonell et al., 2011). The last four parameters were measured with a multiparametric measuring device (WTW, MultiLine P4).

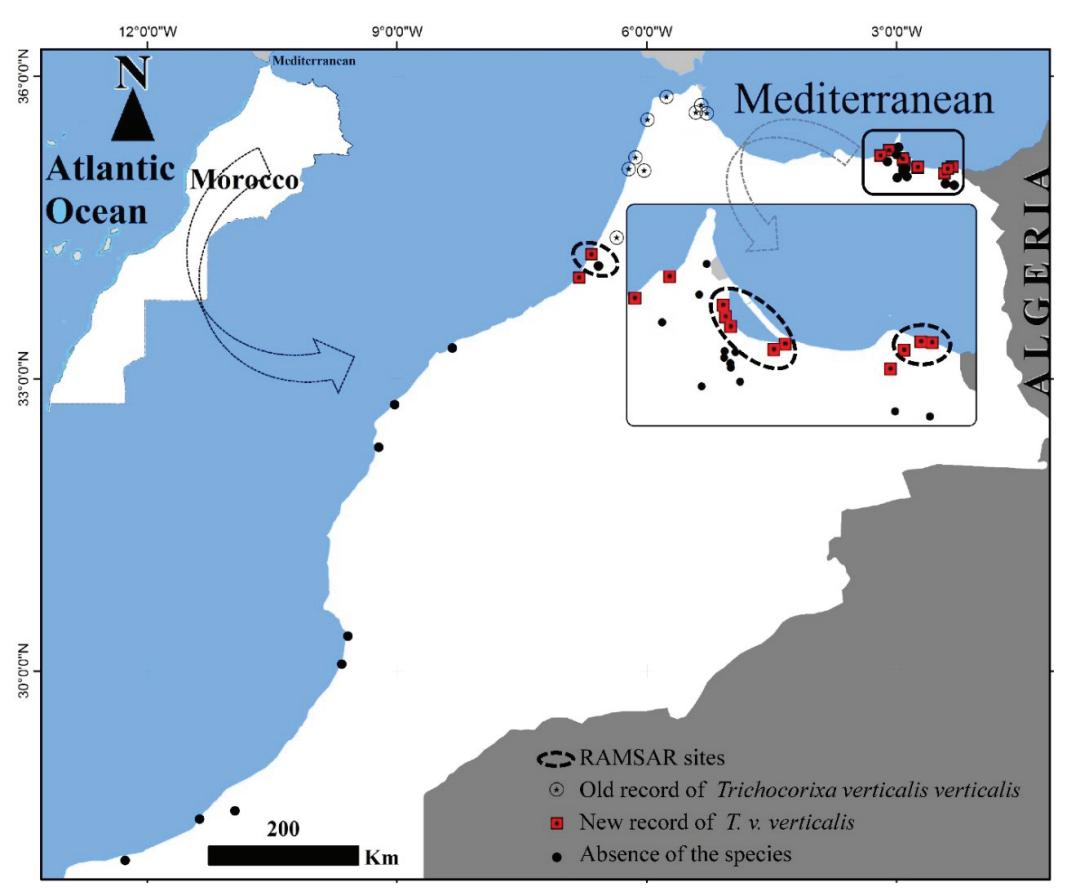

Figure 1. Distribution of T. v. verticalis in North Africa. Note the eastern and southern range expansion of $T v v$ in Morocco (red squares). Distribución de T. v. verticalis en el Norte de África. Destaca la expansión del rango este y sur de Tvv en Marruecos (cuadrados rojos). 
Table 1. The corixid species collected together with T. v. verticalis in the study area. Tvv: Trichocorixa verticalis (Fieber, 1851); Sl: Sigara lateralis (Leach, 1817); Ss: Sigara selecta (Fieber, 1848); Sc: Sigara scripta (Rambur, 1840); St: Sigara stagnalis (Leach, 1817); Pt: Parasigara transversa (Fieber, 1848); Pf: Parasigara favieri (Poisson, 1939); Ca: Corixa affinis Leach, 1817; Cp: Corixa panzeri Fieber, 1848. See Table S1 for sampling sites name. Las especies de corixidos recogidos junto con T. v. verticalis en el área de estudio. Tvv: Trichocorixa verticalis (Fieber, 1851); Sl: Sigara lateralis (Leach, 1817); Ss: Sigara selecta (Fieber, 1848); Sc: Sigara scripta (Rambur, 1840); St: Sigara stagnalis (Leach, 1817); Pt: Parasigara transversa (Fieber, 1848); Pf: Parasigara favieri (Poisson, 1939); Ca: Corixa affinis Leach, 1817; Cp: Corixa panzeri Fieber, 1848. Ver Tabla S1 para el nombre de las estaciones de muestreo.

\begin{tabular}{|c|c|c|c|c|c|c|c|c|c|}
\hline Sampling sites & $T v v$ & $S l$ & Ss & $S c$ & $S t$ & $P t$ & $P f$ & $\mathrm{Ca}$ & $C p$ \\
\hline S51 & 2 & - & - & - & - & - & - & - & - \\
\hline S52 & 143 & - & - & - & - & - & - & - & - \\
\hline S53 & 1 & - & - & - & - & - & - & - & - \\
\hline S54 & 165 & - & - & - & - & - & - & - & - \\
\hline S55 & 35 & - & - & - & - & - & - & - & - \\
\hline S56 & 264 & - & 4 & - & - & - & - & - & - \\
\hline S57 & 25 & - & 75 & - & - & - & - & - & - \\
\hline S57 & 39 & - & - & - & - & - & - & - & - \\
\hline S59 & 1 & - & - & - & - & - & - & - & \\
\hline S70 & 6 & - & 12 & - & - & - & - & - & - \\
\hline S71 & 4 & - & 5 & - & - & - & - & - & - \\
\hline S86 & 2 & - & - & - & - & - & - & - & - \\
\hline S98 & 1 & - & - & - & - & 6 & - & - & - \\
\hline S100 & 1 & - & - & - & - & 22 & - & - & - \\
\hline S104 & 2 & - & - & - & - & - & - & 2 & - \\
\hline S104 & - & 3 & - & - & - & - & - & - & - \\
\hline S104 & 1 & 2 & - & - & - & - & - & 2 & - \\
\hline S105 & 1 & - & - & - & - & - & - & - & - \\
\hline S105 & 2 & - & - & - & - & - & - & - & - \\
\hline S105 & 4 & - & - & - & - & - & - & - & - \\
\hline S158 & 10 & - & - & - & - & - & - & - & - \\
\hline S161 & 12 & - & - & - & - & 7 & - & - & 12 \\
\hline G11 & 34 & 112 & & & & & & & \\
\hline G10 & 12 & & 7 & - & - & - & - & - & - \\
\hline $\mathbf{0 7}$ & 52 & 33 & & - & - & - & - & - & - \\
\hline 019 & 147 & 10 & & - & - & - & - & - & - \\
\hline $\mathbf{N} 2$ & 65 & 110 & & - & - & - & - & - & - \\
\hline N7 & 4 & 39 & 3 & - & - & - & - & - & - \\
\hline N8 & 6 & - & & 1 & 77 & - & - & - & - \\
\hline N18 & 129 & 5 & - & - & - & - & - & - & - \\
\hline N19 & 4 & 1 & - & - & - & - & - & - & - \\
\hline $\mathbf{N} 20$ & 5 & 2 & - & - & - & - & - & - & - \\
\hline N21 & 4 & - & - & - & - & - & - & - & - \\
\hline M21 & 7 & - & 1 & - & - & - & 2 & - & - \\
\hline M22 & 6 & - & 3 & - & - & - & - & - & - \\
\hline
\end{tabular}




\section{Statistical processing of data}

In order to determine the ecological factors addressing the distribution of $T v v$, we built a matrix (see Appendix) showing, for all sampling sites visited combined with those compiled by L'Mohdi et al., (2010) and L'Mohdi (2016), the abundance of $T v v$ and measures of four of the five abiotic parameters considered. Since the conductivity and salinity are almost proportional, we preferred to keep the last factor. For homogenizing variances and minimize the non-normality effects, abundance and the remained parameters selected were $\log (x+1)$ transformed.

We used Pearson's correlations $(\mathrm{R}>0.7)$ to discard variables collinearity and as a first step to understand the relationship between the abundance of $T v v$ and salinity. We further used Multiple Linear Regression (GLM, McCullagh \& Nelder, 1989) to estimates the relationship between salinity and the remained variables. GLM is one of the best known and most applied method in statistics for the analysis of quantitative data determining the dependence between the variable response or dependent numeric variable and several factors or independent numeric variables. Thus, the recorded abundance values of $T v v$ were regressed against the selected environmental variables assuming a Poisson distribution for the dependent variable. Statistical analyses were carried out using $\mathrm{R}$ version 3.3.1 software.

\section{RESULTS}

The alien species $T v v$ have been detected in 30 of the 50 water bodies prospected (Fig. 1 and Table $\mathrm{S} 1$, available at http://www.limnetica.net/en/limnetica), most of them saline or moderately mineralized, near to the coast and, always, at low altitude. We found it for the first time in two Ramsar sites on the Mediterranean coast, the lagoon of Nador and its surroundings, and the wetlands of the Moulouya mouth, respectively. On the Atlantic coast, we also discovered it in the Ramsar site of Sidi Boughaba Lake and in the lower part of Oued Bouregreg (Fig. 1).

$T v v$ was usually accompanied by other species of corixids (Table 1) but mainly by Sigara lateralis (Leach, 1817) in moderate saline or fresh waters, and $S$. selecta in saline waters.

The results of multiple linear regression of abundance versus salinity, altitude, temperature and depth, showed the existence of a clear statistically significant relationship $(p<0.05)$ between abundance and salinity (Table 2 and Fig. 2). In other words, a more saline sampling site is more likely to have a higher abundance of Trichocorixa verticalis verticalis than a less saline one.

\section{DISCUSSION}

Since the first time that the alien species $T v v$ was recorded in Morocco, it has significantly increased its distribution range. After this study,

Table 2. Coefficients of multiple and simple linear regression. Coeficientes de regresión lineal múltiple y simple.

\begin{tabular}{ccccc}
\hline & Estimate & $\begin{array}{c}\text { Std. } \\
\text { Error }\end{array}$ & t value & $\operatorname{Pr}(>|\mathbf{t}|)$ \\
\hline $\begin{array}{c}\text { Multiple linear } \\
\text { regression }\end{array}$ & & & & \\
\hline (Intercept) & 99.662 & 96.788 & 1.03 & 0.312 \\
\hline Sal & $\mathbf{1 . 0 2 4}$ & 0.465 & 2.20 & $\mathbf{0 . 0 3 6 *}$ \\
\hline Alt & -0.655 & 0.949 & -0.69 & 0.496 \\
\hline Temp & -2.752 & 3.694 & -0.75 & 0.462 \\
\hline Dep & -0.210 & 0.243 & -0.87 & 0.393 \\
\hline $\boldsymbol{P}<\mathbf{0 . 0 5}$ & & & & \\
\hline
\end{tabular}


the number of Moroccan Ramsar sites invaded by this species would be five, including Smir and Loukkos wetlands, previously mentioned in L'Modhi et al., (2010). The mouth of the Bouregreg river remains so far the southernmost limit known in the Atlantic coast for this species. In the Mediterranean coast, the mouth of the Moulouya and the city of Saidia were the easternmost limits, also expanding its previously known range (Chavanon et al., 2004; L'Modhi et al., 2010). However, it is probable that the species has already exceeded this limit because of the near presence of available habitats for this species in Algeria. These results give support to the predictions pointed by Guareschi et al. (2013), which expected a wide spread of $T v v$ in several regions of the world, including the coast of the Mediterranean and Atlantic Africa.
$T v v$ seems to be a high-performance as an invader in mineralized wetlands at low altitudes (ranging from 0 to $54 \mathrm{~m}$ ), corroborating the information pointed in previous Iberian studies (Rodríguez-Peréz et al., 2009, Van De Meutter et al., 2010a, Guareschi et al., 2013). Thus, saline stagnant waters near the coast were the most preferred habitat. Nevertheless, it can also colonize artificial channels, and standing and running freshwaters, also showing a euryoic behavior (Carbonell et al., 2017). In fact, the populations studied here were capable to colonize water bodies with strong mineralization differences, fluctuating between 0.1 and $100 \mathrm{~g} / 1$. This ability to tolerate a broad salinity range should be a key feature of its success as an invader too. Its capability to live in hypersaline environments, for instance by osmoregulation mechanisms, but also
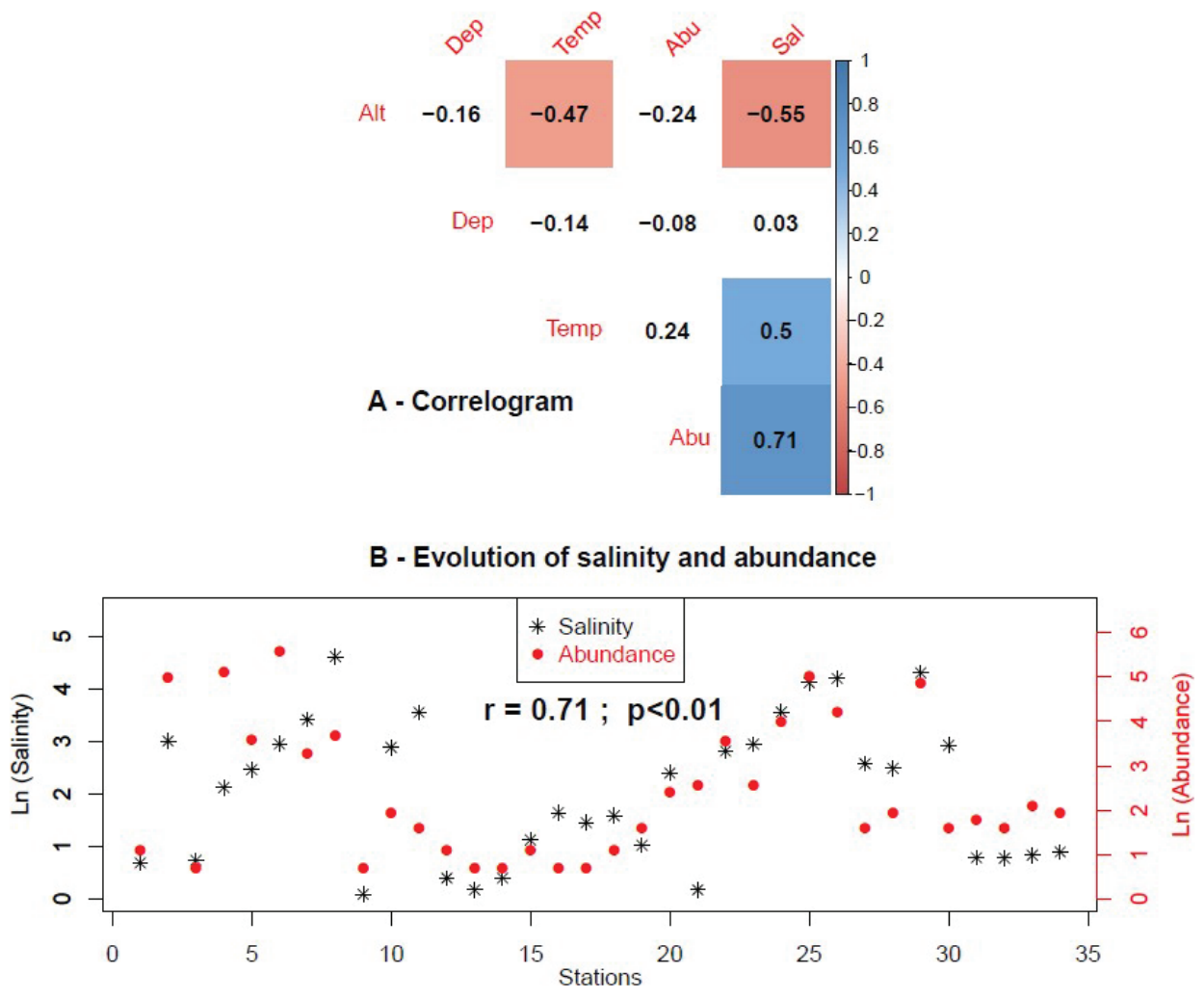

Figure 2. A. Correlogram of the variables (Dep: mean water depth; Temp: temperature; Abu: abundance; Sal: salinity; blue: positive correlation; red: negative correlation) analyzed in the study; B: Evolution of salinity and abundance, showing the Pearson's coefficient value and significance level. A. Correlograma de las variables (Dep: profundidad media del agua; Temp: temperatura; Abu: abundancia; Sal: salinidad; azul: correlación positiva, rojo: correlación negativa) analizadas en el estudio; B: Evolución de la salinidad y la abundancia, mostrando el valor y nivel de significación del coeficiente de Pearson.. 
to colonize different types of habitats, including brackish, freshwater, standing or running water bodies (Günter \& Christmas, 1959; Kelts 1979) probably gives an advantage to $T v v$ against other native corixids.

The capacity of $T v v$ to live in hypersaline waters would also play a key role allowing it to fill a relatively empty niche (Van De Meutter et al., 2010b; Coccia et al., 2013). Nevertheless, the successful invasion of $T v v$ cannot be simply explained on the basis of the mentioned osmoregulation ability to cope with saline aquatic habitats, but other factors such as release from enemies, higher plasticity, elevate reproductive rate and great dispersal capability may account for its success (Carbonell et al., 2015). Although, its range closely linked to coastal areas and low altitudes, with little variability in climatic conditions, could be a limitation for its aquatic inland expanding success.

Van De Meutter et al. (2010b) also indicate the important role of salinity for the occurrence of $T v v$ may also be mediated by disturbance. It appears that despite salinity mainly explains the presence of $T v v$, the anthropogenic disturbance could explain the absence of other corixid species because of the reduction of salinity by dilution. In Larache salt-pans, in 2002, Sigara selecta populations were more abundant than those of $T v v$. In 2004 S. selec$t a$, was found in very low density (L'Modhi et al., 2010). This change may be due to the Tvv competence, but also by the fact that these active salines are suffering an important human pressure.

Furthermore, $T v v$ is capable to live and reproduce in freshwater (Carbonell et al., 2015). A recent study suggests that this pattern is common in species inhabiting saline waters, which are generalists in their fundamental niches, with a predominance of high specimen survival in freshwater or low salinity conditions, where their fitness tends to be similar or even higher than in saline waters (Arribas et al., 2019). Thus, the reasons for its low abundance in these freshwater habitats are still poorly understood. Some suggested reasons included those related with the limited ability of the alien species to withstand the extreme cold in continental areas and at high altitudes (Guareschi et al., 2013), which could explain its absence or rare presence in inland freshwater bodies. In addition, the stronger competitiveness in freshwater with native species (Rodríguez-Pérez et al., 2009), or the pressure by predators such as Odonata larvae could be other factors explaining why $T v v$ is particularly dominant in saline habitats and rare in freshwater anywhere (Coccia et $a l ., 2014)$. In low salinity conditions, $T v v$ also showed higher parasitism rate by water mites Hydrachna skorikowi Piersig 1900 and Eylais infundibulifera Koenike 1897 than native Sigara species (Sánchez et al., 2015).

Despite the mentioned advantages that makes $T v v$ more competitive than the native corixids, it seems that its expansion affects slightly the corixids community in saline waters but not freshwater habitats. It has been proven that the presence of the alien species modifies the distribution and co-occurrence patterns of the native corixids (Carbonell et al., 2017). This study states that, the mechanism that allows coexistence between the alien and the native species appears to be related with niche differentiation, enabling resource partitioning and, consequently, less impact on the native community.

However, its apparent low impact on native corixids, mainly focused on most saline specialists, might change under a scenario of climatic warming, where greater evapotranspiration rates are likely to cause further intensification of saline stress (Green et al., 2002; Moss et al., 2009), and as a consequence, species able to cope with higher salinities, like $T v v$ may benefit from ongoing global change expanding its distribution range. In this new framework, the effect of $T v v$ on the entire community, either saline or freshwater, might change significantly. Monitoring the presence and expansion of $T v v$ within invaded areas, as well as studies improving its biological and ecological knowledge, seems of crucial concern to palliate its possible impact on the native community.

\section{ACKNOWLEDGEMENTS}

We would like to thanks Ouassima L'Mohdi, Mohamed El Haissoufi and Nard Bennas for providing information on Trichocorixa veriticalis verticalis. 


\section{REFERENCES}

ARRIBAS, P., C. GUTIÉRREZ-CÁNOVAS, M. BOTELLA, M. CAÑEDO-ARGÜELLES, J. A. CARBONELL, A. MILLÁN, S. PALLARÉS, J. VELASCO \& D. SÁNCHEZFERNÁNDEZ. 2019. Realized but not fundamental niche specialists compose insects communities of saline waters. Philosophical Transaction of the Royal Society B. In press.

BALIAN, E.V., H. SEGERS, C. LÉVÈQUE \& K. MARTENS. 2008. The freshwater animal diversity assessment: an overview of the results. Hydrobiologia, 595: 627-637. DOI: 10.1007/s10750-007-9246-3

CAIOLA, B. N. \& A. DE. SOSTOA. 2005. Possible reasons for the decline of two native toothcarps in the Iberian Peninsula: evidence of competition with the introduced Eastern mosquitofish. Journal of Applied Ichthyology, 2: 358-363. DOI: 10.1111/j.1439-0426.2005. 00684.x

CARBONELL J. A., C. GUTIÉRREZ-CÁNOVAS, D. BRUNO, P. ABELLÁN, J. VELASCO \& A. MILLÁN. 2011. Ecological factors determining the distribution and assemblages of the aquatic hemiptera (Gerromorpha \& Nepomorpha) in the Segura river basin (Spain). Limnetica, 30: 59-70.

CARBONELL, J. A., A. MILLÁN \& J. VELASCO. 2012. Concordance between realised and fundamental niches in three Iberian Sigara species (Hemiptera: Corixidae) along a gradient of salinity and anionic composition. Freshwater Biology, 57 (12): 2580-2590. DOI: $10.1111 /$ fwb.12029

CARBONELL, J. A., A. MILLÁN, A. J. GREEN, V. CÉSPEDES, C. COCCIA \& J. VELASCO. 2015. What traits underpin the successful establishment and spread of the invasive water bug Trichocorixa verticalis verticalis? Hydrobiologia, 768: 273-286. DOI: $10.1007 / \mathrm{s} 10750-015-2556-\mathrm{y}$

CARBONELL, J. A., J. VELASCO, A. MILLÁN, A. J. GREEN, C. COCCIA, S. GUARESCHI \& C. GUTIÉRREZ-CÁNOVAS. 2017. Biological invasion modifies the co-occurrencepatterns of insects along a stress gradient. Functional Ecology, 31: 1957-1968.
DOI: DOI: 10.5061/dryad.1v035/1

CASTILLO, J. M., E. MATEOS-NARANJO, F. J. NIEVA \& E. FIGUEROA. 2008. Plant zonation at salt marshes of the endangered cordgrass Spartina maritima invaded by Spartina densiflora. Hydrobiologia, 614: 363-371. DOI: $10.1007 / \mathrm{s} 10750-008-9520-\mathrm{z}$

CLAVERO, M. \& E. GARCÍA-BERTHOU. 2005. Invasive species are a leading cause of animal extinctions. Trends in Ecology and Evolution, 20: 1-10. DOI: 10.1016/j.tree.2005. 01.003

COCCIA, C., P. CALOSI, L. BOYERO, A.J. GREEN \& D. T. BILTON. 2013. Does ecophysiology determine invasion success? A comparison between the invasive boatman Trichocorixa verticalis verticalis and the native Sigara lateralis (Hemiptera, Corixidae) in south-west Spain. PLoS One, 8(5): e63105. DOI: 10.1371/journal.pone.0063105

COCCIA, C., L. BOYERO \& A. J. GREEN. 2014. Can differential predation of native and alien corixids explain the success of Trichocorixa verticalis verticalis in the Iberian Peninsula? Hydrobiologia, 734: 115-123. DOI: 10.1007/s10750-014-1873-х

CHAVANON, G., A. BERRAHOU, \& A. MILLAN. 2004. Apport à la connaissance des Coléoptères et Hémiptères aquatiques du Maroc oriental: catalogue faunistique. Boletin de la Sociedad Entomológica Aragonesa, 35, 143-162.

CRUZ, M. J., P. SEGURADO, M. SOUSA \& R. REBELO. 2008. Collapse of the amphibian community of the Paul do Boquilobo Natural Reserve (central Portugal) after the arrival of the exotic American crayfish. Herpetological Journal, 18: 197-204.

DUDGEON, D., A. H. ARTHINGTON, M. O. GESSNER, Z-I. KAWABATA, D. J. KNOWLER, C. LÉVEQUE, R. J. NAIMAN, A. H. PRIEUR-RICHARD, D. SOTO, M. L. STIASSNY \& C. A. SULLIVAN. 2006. Freshwater biodiversity: importance, threats, status and conservation challenges. Biological Reviews, 81: 163-182. DOI: 10.1017/ S1464793105006950

FENOGLIO, E., N. BONADA, S. GUARESCHI, M. LOPEZ-RODRIGUEZ, A. MILLAN \& 
M. TIERNO DE FIGUEROA. 2016. Freshwater ecosystems and aquatic insects: A paradox in biological invasions. Biology Letters, 12: 20151075. DOI: $10.1098 / \mathrm{rsbl} .2015 .1075$

GHEIT, A. 1994. Recherches sur la bio-écologie de la faune Hémiptèrologique aquatique Marocaine Hydrocorises et Amphibicorises peuplant des Hydrosystèmes supralittoraux et continentaux. PhD thesis, Rabat, Morocco. 247 pp. in lit.

GREEN, A. J., M. EL HAMZAOUI, M. A. EL AGBANI \& J. FRANCHIMONT. 2002. The conservation status of Moroccan wetlands with particular reference to waterbirds and to changes since 1978. Biological Conservation, 104: 71-82. DOI: 10.1016/S0006-3207(01) 00155-0

GUARESCHI, S., C. COCCIA, D. SÁNCHEZ-FERNÁNDEZ, J. A. CARBONELL, J. VELASCO, L. BOYERO, A. GREEN \& A. MILLÁN. 2013. How Far Could the alien boatman Trichocorixa verticalis verticalis spread? Worldwide estimation of its current and future potential distribution. PLoS One, 8(3): e59757. DOI: 10.1371/journal.pone. 0059757

GÜNTER, G. \& J. CHRISTMAS. 1959. Corixids insects as part of the offshore fauna of the sea. Ecology, 40: 724-725.

GÜNTHER, H. 2004. Trichocorixa verticalis verticalis (Fieber), eine nearktische Ruderwanze in Europa (Heteroptera: Corixidae). Mitteilungen des Internationalen Entomologischen Verereins, 29: 45-49.

HULME, P. E., P. PYSEK \& W. NENTWIG. 2009. Will threat of biological invasions unite the European Union?. Science, 324: 40-41. DOI: $10.1126 /$ science. 1171111

HUTCHINSON, G. E. 1931. On the occurrence of Trichocorixa Kirkdaly (Corixidae, Hemiptera-Heteroptera) in salt water and its zoo-geogaphical significance. American Naturalist, 65: 573-574. DOI: 10.1086/280405

HUTCHINSON, G. E. 1993. The Zoobenthos. John Wiley and Sons. New York. 944 pp.

JANSSON, A. 1982. Notes on some Corixidae (Heteroptera) from New Guines and New Caledonia. Pacific Insects, 24: 95-103.

JANSSON, A. 1986. The Corixidae (Heterop- tera) of Europe and some adjacent regions. Entomologica Fennica, 47: 1-94.

JANSSON, A. \& P. E. REAVELL. 1999. North American species of Trichocorixa (Heteroptera: Corixidae) introduced into Africa. African Entomology, 7: 295-297.

JÁIMEZ-CUÉLLAR, P., S. VIVAS, N. BONADA, S. ROBLES, A. MELLADO, M. ÁlVAREZ, J. AVILÉS, J. CASAS, M. ORTEGA, I. PARDO, et al. 2002. Protocolo Guadalmed (PRECE). Limnetica, 21:187-204.

KELTS, L. J. 1979. Ecology of a tidal marsh corixid, Trichocorixa verticalis (Insecta, Hemiptera). Hydrobiologia, 64: 37-57. DOI: 10.1007/BF00015451

KMENT, P. 2006. A contribution to the faunistics of aquatic and semiaquatic bugs (Heteroptera: Nepomorpha, Gerromorpha) in Portugal. with the review of biology of the Nearctic corixid Trichocorixa verticalis (Fieber, 1851). Boletín Sociedad Entomológica Aragonesa, 1, 38: 359 -361 .

L'MOHDI, O. 2016. Les hemipteres aquatiques du Maroc: Atlas, biogéographie et degré de vulnérabilité. $\mathrm{PhD}$ tesis, Tetouan, Morocco. $260 \mathrm{pp}$.

L'MOHDI, O., N. BENNAS, O. HIMMI, K. HAJJI, M. EL HAISSOUFI, C. HERNANDO, J. A. CARBONELL \& A. MILLAN. 2010. Trichocorixa verticalis verticalis (Fieber, 1851) (Hemiptera, Corixidae): une nouvelle especies exotique au Maroc. Boletin de la Sociedad Entomológica Aragonesa, 46: 395-400.

LARANJEIRA, C. M. \& G. NADAIS. 2008. Eichhornia crassipes control in the largest Portuguese natural freshwater lagoon. EPPO Bulletin, 38: 487-495. DOI: 10.1111/j.13652338.2008.01268.x

LONSDALE, W. M. 1999. Global patterns of plant invasion and the concept of invasibility. Ecology, 80: 1522-1536. DOI: $10.2307 / 176544$

LOVEJOY, T. E. 2006. Protected areas: a prism for a changing world. Trends in Ecology and Evolution, 21: 329-33. DOI: 10.1016/j.tree. 2006.04.005

MCCULLAGH, P. \& J. NELDER. 1989. Generalized Linear Models, Second Edition. Chapman and Hall/CRC Monographs on Statistics 
and Applied Probability Series Chapman \& Hall, 506pp.

MILlÁN, A., C. HERNÁNDO, P. AGUILERA, A. CASTR \& I. RIBERA. 2005. Los coleópteros acuáticos y semiacuáticos de Doñana: Reconocimiento de su biodiversidad y prioridades de conservación. Boletin de la Sociedad Entomológica Aragonesa, 36: 157-164.

MOSS, B., D. HERING, A. J. GREEN, A. AIDOUD, E. BECARES, M. BEKLIOGLU, H. BENNION, D. BOIX, S. BRUCET, L. CARVALHO, B. CLEMENT, T. DAVIDSON, S. DECLERCK, M. DODSON, E. VAN DONK, B. DUDLEY, H. FEUCHTMAYR, N. FRIBERG, G. GRENOUILLET, H. HILLEBRAND, A. HOBAEK, K. IRVINE, E. JEPPESEN, R. JOHNSON, I. JONES, M. KERNAN, T.L. LURIDSEN, M. MANCA, M. MEERHOFF, J. OLAFSSON, S. ORMEROD, E. PAPASTERGIADOU, W. ELLIS PENNING, R. PTACNIK, X. QUINTANA, L. SADIN, M. SEFERLIS, G. SIMPSON, C. TRIGA, P. VERDOSCHOT, M. ANTONIE \& G. A. WEYHENMEYER. 2009. Climate change and the future of freshwater biodiversity in Europe: A primer for policy-makers. Freshwater Reviews, 2: 103-130. DOI: 10.1608/FRJ-2.2.1

NIESER, N., M. BAENA, J. MARTINEZ-AVILES \& A. MILLAN. 1994. Claves para la Identificacion de los Heteropteros acuáticos (Nepomorpha and Gerromorpha) de la peninsula Ibérica- Con notas sobre las especies de las Islas Azores, Baleares, Canarias y Madeira. Asociación Española de Limología. $111 \mathrm{pp}$.

NUNES, A. L., E. TRICARICO, V. E. PANOV, A. C. CARDOSO \& S. KATSANEVAKIS. 2015. Pathways and gateways of freshwater invasions in Europe. Aquatic Invasions, 10, 4 : 359-370. DOI: 10.3391/ai.2015.10.4.01

PIMENTEL, D., R. ZUNIGA \& D. MORRISON. 2005. Update on the environmental and economic costs associated with alien-invasive species in the United States. Ecological Economics 52: 273-288. DOI: 10.1016/j.ecolecon.2004. 10.002

RODRÍGUEZ-PÉREZ， H., C. FLORENCIO GÓMEZ-RODRÍGUEZ, A. J. GREEN, C.
DÍAZ-PANIAGUA \& L. SERRANO. 2009. Monitoring the invasion of the aquatic bug Trichocorixa verticalis verticalis (Hemiptera: Corixidae) in the wetlands of Doñana National Park (SW Spain). Hydrobiologia, 634: 209-217. DOI: 10.1007/978-90-481-9088-1_30

SALA, J. \& D. BOIX. 2005. Presence of the Nearctic water boatman Trichocorixa verticalis verticalis (Fieber, 1851) (Heteroptera, Corixidae) in the Algarve region (S Portugal). Graellsia, 61(1): 31-36. DOI: 10.3989/graellsia.2005. v61.i1.4

SÁNCHEZ, M. I., C. COCCIA, A. G. VALDECASAS, L. BOYERO \& A. GREEN. 2015. Parasitism by water mites in native and exotic Corixidae: Are mites limiting the invasion of the water boatman Trichocorixa verticalis (Fieber, 1851)? Journal of Insects Conservation, 19: 433-447. DOI: 10.1007/s10841-0159764-7

SAVINI, D., A. OCCHIPINTI-AMBROGI, A. MARCHINI, E. TRICARICO, F. GHERARDI, S. OLENIN \& S. GOLLASCH. 2010. The top 27 animal alien species introduced into Europe for aquaculture and related activities. Journal of Applied Ichthyology, 26: 1-7. DOI: 10.1111/j.1439-0426.2010.01503.x

VAN DE MEUTTER, F., H. TREKELS \& A. J. GREEN. 2010a. The impact of the North American waterbug Trichocorixa verticalis (Fieber) on aquatic macroinvertebrate communities in southern Europe. Fundamental and Applied Limnology / Archiv Für Hydrobiologie, 177: 283-292. DOI: 10.1127/1863-9135/ 2010/0177-0283

VAN DE MEUTTER, F., H. TREKEKLS, A. J. GREEN \& R. STOKS. 2010b. Is salinity tolerance the key to success for the invasive water bug Trichocorixa verticalis?. Hydrobiologia, 649: 231-238. DOI: 10.1007/s10750-0100250-7

VITOUSEK, P. M., C. M. D’ANTONIO, L. LOOPE, M. REJMÁNEK \& R. WESTBROOKS. 1997. Introduced species: a significant component of human-caused global environmental change. New Zealand Journal of Ecology, 21: 1-16.

WILSON, J. R. U., E. E. DORMONTT, P. J. PRENTIS, A. J. LOWE \& D. M. RICHARD- 
SON. 2009. Something in the way you move: dispersal pathways affect invasion success.
Trends in Ecology and Evolution, 24: 136-144. DOI: 10.1016/j.tree.2008.10.007

Con el patrocinio de:
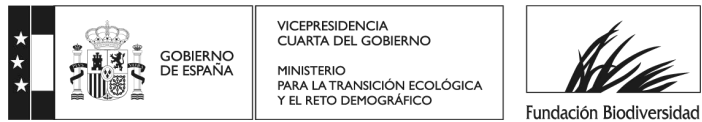

Fundación Biodiversidad 